\title{
Relationship Between Microstructure and Corrosion Behavior of Cr12Ni3Co12Mo4W Ultra-High-Strength Martensitic Stainless Steel
}

\author{
Hui-Yan $\mathrm{Li}^{1} \cdot$ Chao-Fang Dong ${ }^{1} \cdot \mathrm{Kui}^{\mathrm{Xiao}}{ }^{1} \cdot{\mathrm{Xiao}-G a n g ~ \mathrm{Li}^{1}}^{1}$ Ping $\mathrm{Zhong}^{2}$
}

Received: 20 May 2016/Revised: 25 July 2016/Published online: 7 September 2016

(C) The Chinese Society for Metals and Springer-Verlag Berlin Heidelberg 2016

\begin{abstract}
The effect of tempering temperature on the microstructure and corrosion behavior of Cr12Ni3Co12Mo4W ultra-high-strength martensitic stainless steel was investigated using transmission electron microscopy, atomic force microscopy, X-ray diffraction, and electrochemical tests. The microstructures of the ultra-high-strength martensitic stainless steel consisted of some retained austenite and lath/plant martensite with the carbides distributed within the matrix and at the grain boundaries. Tempering of the steel for $4 \mathrm{~h}$ at various temperatures resulted in various carbide grain sizes and different amounts of the retained austenite. The results showed that larger carbide grains led to diminished corrosion resistance, whereas larger amounts of the retained austenite resulted in improved corrosion resistance. The steels exhibited good corrosion resistance in $0.017 \mathrm{~mol} / \mathrm{L} \mathrm{NaCl}$ solution and exhibited pitting corrosion in $0.17 \mathrm{~mol} / \mathrm{L} \mathrm{NaCl}$ solution. The martensite and prior austenite crystal boundaries dissolved in solution with $\mathrm{pH} 1$.
\end{abstract}

KEY WORDS: Heat treatment; Martensite; Retained austenite; Carbide; Corrosion behavior

\section{Introduction}

Applications such as tissue engineering, aircraft devices, and ocean equipment require steels with a combination of high specific strength and good durability. The use of multi-component martensitic stainless steels in high stress and corrosive environments requires a better understanding of the passive film formation, the breakdown behavior during exposure to aggressive ions, and the consequent effects on pitting or failure. Previous studies have demonstrated that the corrosion resistance

Available online at http://link.springer.com/journal/40195

Chao-Fang Dong

cfdong@ustb.edu.cn

1 Corrosion and Protection Center, Key Laboratory for Corrosion and Protection (MOE), University of Science and Technology Beijing, Beijing 100083, China

2 Beijing Institute of Aeronautical Materials, Beijing 100095, China of the martensitic stainless steel is generally better in the hardened condition than in the annealed or soft condition [1-5]. Martensitic stainless steels containing (11-13) \% Cr exhibit good electrochemical properties. Sun et al. studied the electrochemical behaviors of Cr9Ni5MoCo14 and Cr12Ni4Mo2Co14 martensitic stainless steels, and their results indicated that the steels' passive films dramatically affected their corrosion resistances [6, 7].

Because the properties of the martensitic stainless steels can be greatly changed by heat treatment, therefore the heat treatment parameters must be carefully controlled to ensure that the steels possess appropriate structures achieving the desired properties. For example, the amount and the grain size of the carbide precipitates can affect the steel's hardness [8-12]. Martensitic stainless steel consists of the martensite, undissolved carbides, and retained austenite [13] and exhibits greater strength than austenite, which makes the steel achieve ultra-high strength in the martensitic steels. However, the poor corrosion resistance of the martensite is problematic [14]. 
Heat treatment parameters play a critical role in producing suitable microstructures and can affect the mechanical properties and corrosion behavior of the steels [15-19].

The presence of the retained austenite, making the austenite fail to transform into martensite during the cooling process, may positively affect the wear resistances, fatigue properties, and ductility of the steels. However, the retained austenite deteriorates the pitting corrosion resistances of the steels because it results in the formation of $\mathrm{Cr}$ depleted zones [15]. Li et al. [20] deduced that the coarsened grains were the main contributor to good intergranular corrosion resistance. Choi et al. [21] concluded that the better corrosion resistance of the martensitic stainless steels with $13 \% \mathrm{Cr}$ is related to the dissolution of the carbides, whereas the precipitation of $\mathrm{Cr}$-rich $M_{23} \mathrm{C}_{6}$ and $M_{7} \mathrm{C}_{3}$ carbides reduces the resistance of passive films, enhancing pitting corrosion. Bilmes et al. reported that the presence and amount of the retained austenite as a microstructural component resulting from the applied heat treatments can improve the pitting corrosion resistances of both weld and parent metal 13CrNiMo stainless steels [22]. Most of the previous researches have focused on the microstructures and corrosion behaviors of the austenite stainless steel [23-26] and the martensitic stainless steel. However, the literature contains few studies on the effect of the microstructure on the corrosion behavior of ultra-highstrength martensitic stainless steel (UHSMSS).

Further work based on our previous studies is underway on the subject of passivity and pitting corrosion of Cr12Ni3Co12Mo4W in support of our principal objective of elucidating the correlations among the heat treatment process and the steel's microstructure, mechanical properties, and corrosion behavior. We are seeking new insights to enhance the corrosion resistance of this steel, which combines the advantages of the martensite and stainless steel.

In the present study, we investigated the effects of heat treatment on the microstructure and corrosion behavior of a novel UHSMSS by using transmission electron microscopy (TEM), atomic force microscopy, X-ray diffraction (XRD), and electrochemical analyses. The samples with various carbide grain sizes and different amounts of the retained austenite were tempered at different temperature for $4 \mathrm{~h}$.

\section{Experimental}

\subsection{Experimental Material}

Cr12Ni3Co12Mo4W UHSMSS with the chemical composition listed in Table 1 was used in this study. The UHSMSS was heated by austenitizing at $1080^{\circ} \mathrm{C}$ for $30 \mathrm{~min}$, oil quenching to room temperature, followed by treatment for $1 \mathrm{~h}$ at $-73{ }^{\circ} \mathrm{C}$ to transform the retained austenite, and finally tempering at 400,520 , and $600{ }^{\circ} \mathrm{C}$ for $4 \mathrm{~h}$. A schematic of the heat treatment process is shown in Fig. 1.

The samples were ground, polished, and then etched with a solution ( $\left.\mathrm{HF}: \mathrm{HCl}: \mathrm{H}_{2} \mathrm{O}=4: 4: 92\right)$ to reveal the microstructure under a stereologic microscope (KEYENCE VHX-2000C). The microstructure of UHSMSS consists of some retained austenite and lath/plant martensite with the carbides distributed within the matrix and at the grain boundaries.

\subsection{Transmission Electron Microscopy and Atomic Force Microscopy}

A JEM-2100F high-resolution transmission electron microscope operated at $200 \mathrm{kV}$ was used to observe the microstructures of as-prepared NPC specimens. The specimens were thinned by a Gatan 691 precision ion polishing system using Ar ions at $5 \mathrm{kV}$.

The surface height and potential morphology of the etched surface of the Cr12Ni3Co12Mo4W UHSMSS tempered at $600{ }^{\circ} \mathrm{C}$ were observed using an atomic force microscope (Bruker MultiMode 8.0) in tapping mode.

\subsection{X-ray Diffraction}

Volume fractions of the retained austenite in three kinds of the samples were analyzed by Rietveld analysis of XRD data. The XRD patterns were collected at room temperature with a Philips PW 1710 diffractometer equipped with a diffractedbeam graphite monochromator. The data were collected using $\mathrm{Cu} K_{\alpha}$ radiation at angles of $10^{\circ} \leq 2 \theta \leq 100^{\circ}$ in steps of $0.02^{\circ}$. Rietveld analysis was performed using the Fullprof program. The amounts of the retained austenite in three kinds of UHSMSSs, as determined by this analysis, are listed in Table 2.

Table 1 Chemical composition of the Cr12Ni3Co12Mo4W UHSMSS (wt $\%$ )

\begin{tabular}{llllllllll}
\hline $\mathrm{C}$ & $\mathrm{Cr}$ & $\mathrm{Co}$ & $\mathrm{Mo}$ & $\mathrm{Ni}$ & $\mathrm{W}$ & $\mathrm{V}$ & $\mathrm{Ti}$ & $\mathrm{Si}$ & $\mathrm{Mn}$ \\
\hline 0.089 & 12.41 & 12.3 & 4.43 & 2.59 & 0.98 & 0.24 & $<0.005$ & 0.053 & $<0.10$ \\
\hline
\end{tabular}




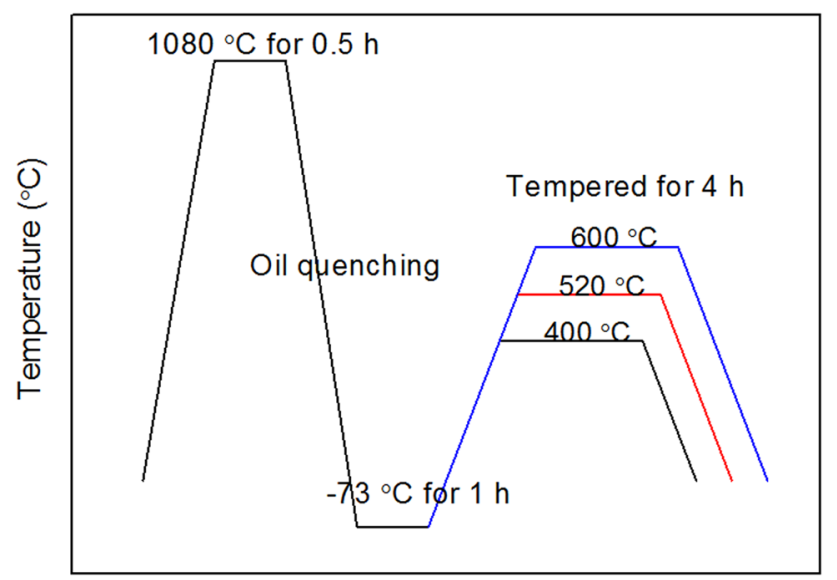

Time (h)

Fig. 1 Schematic of heat treatment process on the Cr12Ni3Co12Mo4W UHSMSS

\subsection{Electrochemical Tests}

All of the samples were embedded in epoxy resin, leaving a working area of $1 \mathrm{~cm}^{2}$; the samples were subsequently ground to 1000 grit and cleaned with ethanol and deionized water before the tests. The test solutions were $0.1 \mathrm{~mol} / \mathrm{L}$ $\mathrm{Na}_{2} \mathrm{SO}_{4}+0.017 \mathrm{~mol} / \mathrm{L} \mathrm{NaCl}(\mathrm{pH} 3)$ and $0.1 \mathrm{~mol} / \mathrm{L} \mathrm{Na}$ $\mathrm{SO}_{4}+0.17 \mathrm{~mol} / \mathrm{L} \mathrm{NaCl}(\mathrm{pH} 3)$. All of the solutions were prepared from analytical-grade $98 \% \mathrm{H}_{2} \mathrm{SO}_{4}$ and deionized water, and all of the tests were carried out at room temperature. The electrochemical measurements were taken in a conventional three-electrode cell using an M370 advanced electrochemical system. The UHSMSS samples were used as the working electrodes, a platinum sheet was used as the counter electrode, and all of the potentials were measured against a saturated calomel electrode (SCE) connected to the cell via a Luggin probe.

Prior to the electrochemical measurements, the working electrodes were initially reduced potentiostatically at $-1.2 \mathrm{~V}_{\mathrm{SCE}}$ for $3 \mathrm{~min}$ to remove air-formed oxides. Electrochemical impedance spectroscopy (EIS) was performed using an applied potential amplitude of $10 \mathrm{mV}$ at the open-circuit potential in the frequency range from $100 \mathrm{kHz}$ to $10 \mathrm{mHz}$. The polarization curves were measured potentiodynamically from $-0.3 \mathrm{~V}$ (vs. corrosion potential $\left.E_{\text {corr }}\right)$ to $1.8 \mathrm{~V}_{\mathrm{SCE}}$ at a scanning rate of $0.5 \mathrm{mV} / \mathrm{s}$.
The surface morphologies of the UHSMSS were observed under a stereologic microscope (KEYENCE VHX-2000C) after the samples had been immersed for $10 \mathrm{~min}$ and subjected to a potentiodynamic polarization test in $0.1 \mathrm{~mol} / \mathrm{L} \mathrm{Na}_{2} \mathrm{SO}_{4}+0.17 \mathrm{~mol} / \mathrm{L} \mathrm{NaCl}(\mathrm{pH} 1)$ solution.

\section{Results and Discussion}

\subsection{Microstructure of UHSMSS}

The microstructures of the samples subjected to various heat treatments are shown in Fig. 2. The microstructure of UHSMSS consists of some retained austenite and lath/plant martensite with the carbides distributed within the matrix and at the grain boundaries. The lath martensites are arranged in parallel along the austenite grain boundaries. The amount of retained austenite (the blank areas in the figures) in the microstructure of the steel tempered at $400{ }^{\circ} \mathrm{C}$ is larger than those in the microstructures of the steel tempered at other temperatures.

The carbide precipitates at the boundaries of the martensite plates and within the martensite matrix were further inspected by TEM, as shown in Fig. 3. The microstructures of the steels subjected to various heat treatments are clearly different. The grain sizes of the carbides are listed in Table 2 . No obvious carbide precipitates are evident in the UHSMSS sample tempered at $400{ }^{\circ} \mathrm{C}$ for $4 \mathrm{~h}$ (Fig. 3a). The carbide grain size is approximately $200 \mathrm{~nm}$ in the sample tempered at $520{ }^{\circ} \mathrm{C}$ (Fig. 3b) and decreases dramatically to $100 \mathrm{~nm}$ in the sample tempered at $600{ }^{\circ} \mathrm{C}$ (Fig. 3c). These carbides were indexed as $M_{23} \mathrm{C}_{6}$ based on their corresponding electron diffraction patterns (Fig. 3d), similar to the carbides in 1Cr12NiMo martensitic stainless steel also reported by Fan [9].

The results in Fig. 3 also reveal that the martensite lath sizes differ in the microstructures of the steels subjected to different heat treatments. When the tempering temperature increases from 400 to $520{ }^{\circ} \mathrm{C}$, the martensite laths appear to be more refined. However, when the aging temperature increases from 520 to $600{ }^{\circ} \mathrm{C}$, the martensite laths appear to be coarsened. We assume that, for the experimental steel, the best temperature for refining martensite lath is

Table 2 Microstructure of $\mathrm{Cr} 12 \mathrm{Ni} 3 \mathrm{Co} 12 \mathrm{Mo} 4 \mathrm{~W}$ UHSMSS subjected to various heat treatments

\begin{tabular}{llll}
\hline & $400{ }^{\circ} \mathrm{C}$ & $520{ }^{\circ} \mathrm{C}$ & $600{ }^{\circ} \mathrm{C}$ \\
\hline Microstructure & Martensite + retained austenite & Martensite + retained austenite + carbide & Martensite + retained austenite + carbide \\
Retained austenite & $4.74 \%$ & $0.4 \%$ & $1.48 \%$ \\
Carbide grain size & 0 & $200 \mathrm{~nm}$ & $100 \mathrm{~nm}$ \\
\hline
\end{tabular}



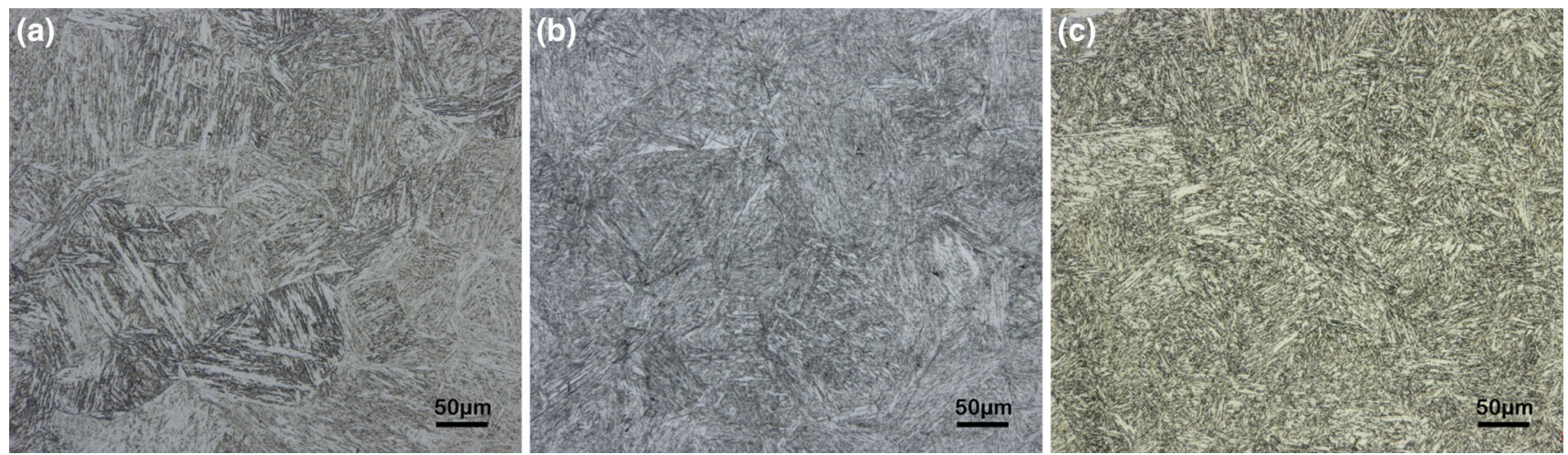

Fig. 2 Microstructures of the $\mathrm{Cr} 12 \mathrm{Ni} 3 \mathrm{Co} 12 \mathrm{Mo} 4 \mathrm{~W}$ UHSMSS samples subjected to various heat treatments of a $400{ }^{\circ} \mathrm{C}, \mathbf{b} 520{ }^{\circ} \mathrm{C}$, c $600{ }^{\circ} \mathrm{C}$

$520{ }^{\circ} \mathrm{C}$. Refined martensite lath is generally considered to enhance the strength of martensitic stainless steels.

The TEM bright-field image (Fig. 3a) clearly shows that the retained austenite formed within the martensite matrix after tempering at $400{ }^{\circ} \mathrm{C}$ for $4 \mathrm{~h}$ and formed along the martensite lath boundaries in the specimen tempered at $600{ }^{\circ} \mathrm{C}$ (Fig. 3c). (Retained austenite formed within the martensite matrix and at the boundaries at both 400 and $600{ }^{\circ} \mathrm{C}$; the images show local areas.) Retained austenite is hardly observable in the microstructure of UHSMSS tempered at $520{ }^{\circ} \mathrm{C}$ for $4 \mathrm{~h}$. The amounts of the retained austenite in the microstructures of the UHSMSS samples subjected to different heat treatments, as measured by $\mathrm{XRD}$, are listed in Table 2. The amount of the retained austenite is $4.74 \%$ in the UHSMSS sample tempered at $400{ }^{\circ} \mathrm{C}$, which is twice the amount in the sample tempered at $600{ }^{\circ} \mathrm{C}$. The smallest amount $(0.4 \%)$ is evident for the sample tempered at $520{ }^{\circ} \mathrm{C}$.

The height and potential morphology of the etched surface of the Cr12Ni3Co12Mo4W UHSMSS tempered at $600{ }^{\circ} \mathrm{C}$ are shown in Fig. 4. As evident in Fig. 4a, the surface height difference is approximately $200 \mathrm{~nm}$, consistent with the size observed in Fig. 3. In addition, the 3D potential morphology shows that the surface potential of the UHSMSS is uniform. According to the results of the metallographic observations and TEM analysis, the martensite is the predominant phase in Fig. 4.

\subsection{Effect of Heat Treatment on Microstructure}

Martensitic stainless steels are commonly used in their quenched and tempered conditions. The quenching heat treatment involves annealing to obtain austenite and dissolve the carbides, followed by cooling to transform the austenite into martensite and induce carbide precipitation. The heat treatment parameters play a critical role in determining the carbide grain size and the amount of the retained austenite. Garcia et al. [27] reported that the amount of the carbides in the quenching microstructures of $0.45-13 \mathrm{Cr}$ steel can be substantially modified through control of the heating and cooling conditions used in the heat treatment. Although they studied the influences of the heating parameters and the cooling rate on the carbide amounts, they did not investigate the influence of the tempered temperature.

The UHSMSS was tempered to transform the austenite into the martensite. The sample tempered at $400{ }^{\circ} \mathrm{C}$ contained more retained austenite than that tempered at $520{ }^{\circ} \mathrm{C}$. We concluded that the amount of the retained austenite in the tempered microstructure of the UHSMSS decreases with increasing tempering temperature, resulting in more complete transformation. However, the amount of the retained austenite in the steel sample tempered at $520{ }^{\circ} \mathrm{C}$ was smaller than that in the sample tempered at $600{ }^{\circ} \mathrm{C}$. We therefore concluded that the amount of the retained austenite in the tempered microstructure of the UHSMSS decreased as the tempering temperature increased from 400 to $520{ }^{\circ} \mathrm{C}$ and increased as the tempering temperature increased from 520 to $600{ }^{\circ} \mathrm{C}$. Because the mechanical properties of the steels are known to be improved with decreasing amount of the retained austenite, a tempering temperature of $520{ }^{\circ} \mathrm{C}$ is the optimal condition for achieving excellent mechanical properties.

The carbides were dissolved during the annealing process, but were precipitated during the tempering process. For the test steel, the carbide grain size was largest in the sample tempered at $520^{\circ} \mathrm{C}$ and was second largest in the sample tempered at $600{ }^{\circ} \mathrm{C}$; by contrast, the carbides were hardly observed in the microstructure of the UHSMSS sample tempered at $400{ }^{\circ} \mathrm{C}$. Because the carbides are known to cause high hardness of steels, the tempering temperature of $520^{\circ} \mathrm{C}$ is optimal for achieving excellent mechanical properties; tempering at $600{ }^{\circ} \mathrm{C}$ is the secondbest tempering condition, whereas tempering at $400{ }^{\circ} \mathrm{C}$ results in the lowest hardness. The optimal parameters for achieving a specific property vary for different steels, and 

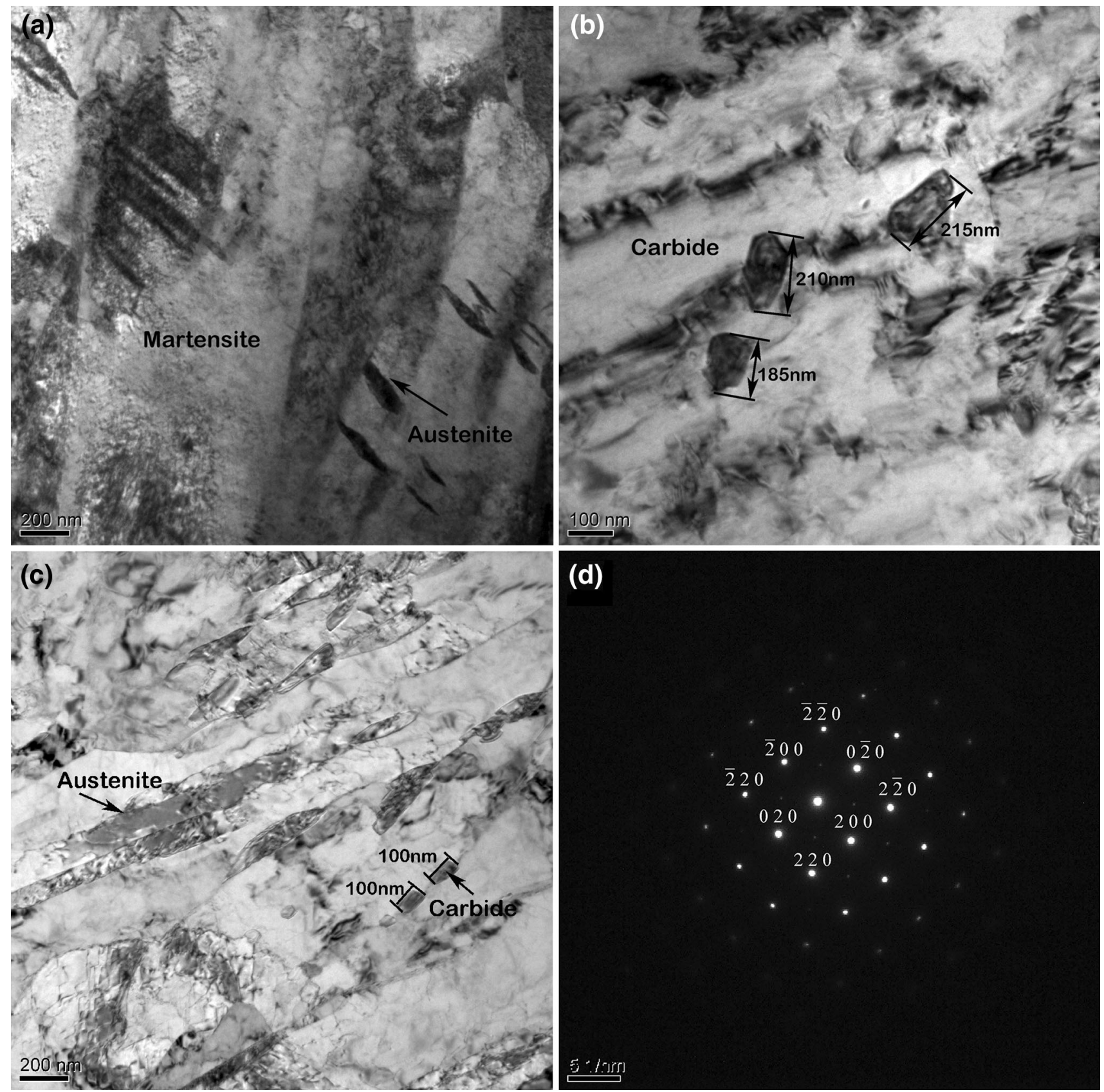

Fig. 3 TEM micrographs of the Cr12Ni3Co12Mo4W UHSMSS subjected to various tempered temperatures a $400{ }^{\circ} \mathrm{C}$, b $520{ }^{\circ} \mathrm{C}$, c $600{ }^{\circ} \mathrm{C}$, d corresponding electron diffraction pattern from the carbide in $\mathbf{b}$

the optimal parameters for achieving excellent mechanical properties are not always the best conditions for achieving good electrochemical properties.

\section{Effect of Carbides on Corrosion Behavior}

Figure 5 shows the potentiodynamic polarization curves of three kinds of steels measured in $0.1 \mathrm{~mol} / \mathrm{L} \mathrm{Na}_{2}$ $\mathrm{SO}_{4}+0.017 \mathrm{~mol} / \mathrm{L} \mathrm{NaCl}(\mathrm{pH} 3)$ solution. As shown in
Fig. 4, the three kinds of steels exhibit good electrochemical characteristics in the mild environment. The polarization curves consist of four primary parts: (1) cathodic section (a-b), (2) anodic dissolution sections $(\mathrm{b}-\mathrm{c}),(3)$ passivity sections (c-d), and (4) trans-passive sections (d-e). A similar phenomenon was also observed in the ultra-high-strength steel AerMet100 in $\mathrm{H}_{2} \mathrm{SO}_{4}+\mathrm{Na}_{2} \mathrm{SO}_{4}$ solution [28].

The corrosion potential of the UHSMSS in $0.1 \mathrm{~mol} / \mathrm{L}$ $\mathrm{Na}_{2} \mathrm{SO}_{4}+0.017 \mathrm{~mol} / \mathrm{L} \quad \mathrm{NaCl} \quad(\mathrm{pH} \quad 3)$ solution is 
(a)

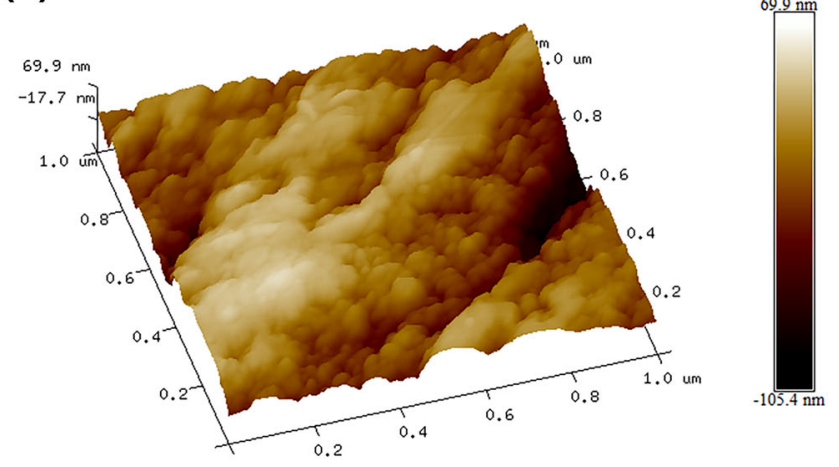

Height

$200.0 \mathrm{~nm}$ (b)

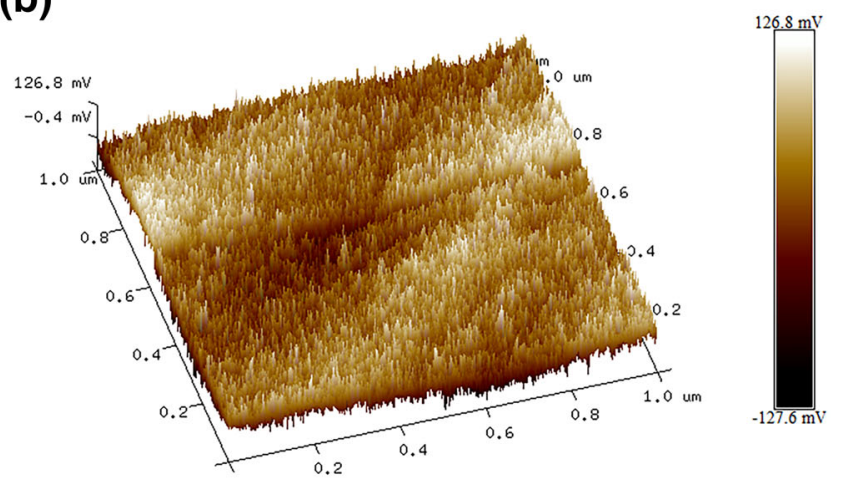

Potential

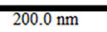

Fig. 4 3D AFM height (a) and potential (b) morphologies of the etched surface of the $\mathrm{Cr} 12 \mathrm{Ni} 3 \mathrm{Co} 12 \mathrm{Mo} 4 \mathrm{~W}$ UHSMSS tempered at $600{ }^{\circ} \mathrm{C}$

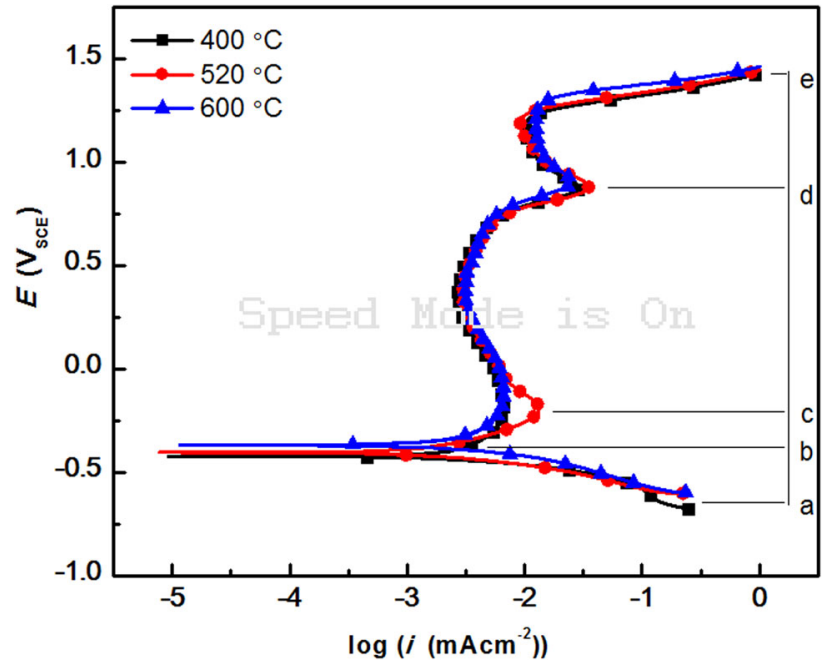

Fig. 5 Potentiodynamic polarization curves for the UHSMSS in $0.1 \mathrm{~mol} / \mathrm{L} \mathrm{Na}_{2} \mathrm{SO}_{4}+0.017 \mathrm{~mol} / \mathrm{L} \mathrm{NaCl}(\mathrm{pH} 3)$ solution

approximately $-0.4 \mathrm{~V}_{\mathrm{SCE}}$, which is lower than that of some other ultra-high-strength steels such as AerMet100 steel [28]. The potential in the passivity region ranges from $-0.25 \mathrm{~V}_{\mathrm{SCE}}$ to $0.85 \mathrm{~V}_{\mathrm{SCE}}$. The low concentration of $\mathrm{Cl}^{-}$ did not cause pitting corrosion on the UHSMSS. The three kinds of UHSMSS subjected to different heat treatments exhibit excellent corrosion resistances in $0.1 \mathrm{~mol} / \mathrm{L} \mathrm{Na}_{2}$ $\mathrm{SO}_{4}+0.017 \mathrm{~mol} / \mathrm{L} \mathrm{NaCl}(\mathrm{pH} 3)$ solution.

Figure 6 shows the potentiodynamic polarization curves for three steels measured in $0.1 \mathrm{~mol} / \mathrm{L} \mathrm{Na}_{2} \mathrm{SO}_{4}+0.17$ $\mathrm{mol} / \mathrm{L} \mathrm{NaCl}(\mathrm{pH} 3)$ solution. The corrosion potentials for the steels are similar: approximately $-0.4 \mathrm{~V}_{\mathrm{SCE}}$. However, the pitting potentials differ substantially. The pitting potential of the steel tempered at $400{ }^{\circ} \mathrm{C}$ is the highest, at $0.85 \mathrm{~V}_{\mathrm{SCE}}$ (point $\mathrm{d}_{3}$ ); thus, this steel exhibits the best pitting corrosion resistance. As shown in Fig. 3a, the microstructure of the steel tempered at $400{ }^{\circ} \mathrm{C}$ is mainly

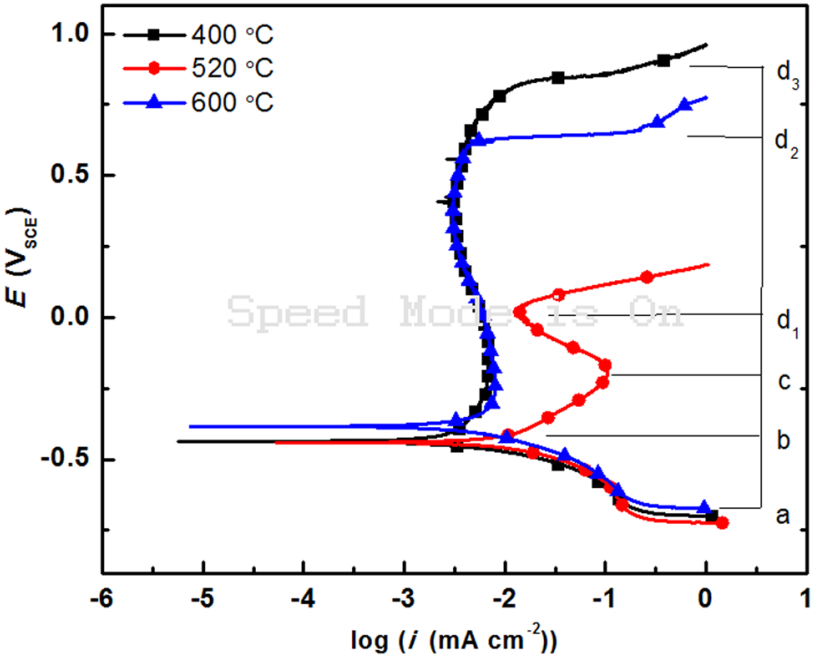

Fig. 6 Potentiodynamic polarization curves for the UHSMSS in $0.1 \mathrm{~mol} / \mathrm{L} \mathrm{Na}_{2} \mathrm{SO}_{4}+0.17 \mathrm{~mol} / \mathrm{L} \mathrm{NaCl}(\mathrm{pH} 3)$ solution

lath/plant martensitic with a few carbide precipitates in the martensitic matrix. We assume that this microstructure of the steel contributed to its good corrosion resistance.

The pitting potential of the steel tempered at $520{ }^{\circ} \mathrm{C}$ is the lowest, at $0 \mathrm{~V}_{\mathrm{SCE}}$ (point $\mathrm{d}_{1}$ ). This sample exhibits the worst pitting corrosion resistance among the investigated samples. As shown in Fig. 3b, the microstructure of the steel tempered at $520{ }^{\circ} \mathrm{C}$ is mainly lath/plant martensitic, with some large carbide precipitates in the martensitic matrix. Choi et al. [21] reported that the better corrosion resistance of the martensitic stainless steels with $13 \% \mathrm{Cr}$ is related to the dissolution of the carbides; the precipitations of Cr-rich $M_{23} \mathrm{C}_{6}$ and $M_{7} \mathrm{C}_{3}$ carbides reduce the resistances of passive films, thereby enhancing pitting corrosion. Based on the selected-area electron diffraction pattern, we indexed these large carbides as $M_{23} \mathrm{C}_{6}$. We concluded that the carbide precipitation induces pitting corrosion. The 
microstructure was uneven when the carbide precipitates were present; these steels were easily corroded because the potential of the carbide is lower than that of the martensitic matrix. Thus, the carbide concentration decreases, which leads to pitting.

The pitting potential of the steel tempered at $600{ }^{\circ} \mathrm{C}$ is $0.6 \mathrm{~V}_{\mathrm{SCE}}$ (point $\mathrm{d}_{2}$ ), which is in the intermediate between the potentials of the steels tempered at 400 and $520{ }^{\circ} \mathrm{C}$. As shown in Fig. 3c, the microstructure of the steel tempered at $600{ }^{\circ} \mathrm{C}$ is mainly lath/plant martensitic, with a few small carbide precipitates in the martensitic matrix.

Figure 7 shows the carbide grain size plotted against the pitting potential $E_{\mathrm{p}}$ for steel samples subjected to different heat treatment conditions. The pitting potential, which is the breakdown potential of passivation, decreases from $0.85 \mathrm{~V}_{\mathrm{SCE}}$ to $0 \mathrm{~V}_{\mathrm{SCE}}$ as the carbide grain size increases from 0 to $200 \mathrm{~nm}$, indicating that the bigger carbide grains result in greater susceptibility to pitting corrosion. We assume that the undissolved and precipitated carbides deteriorated the corrosion resistance of the specimen in $0.1 \mathrm{~mol} / \mathrm{L} \mathrm{Na} \mathrm{Na}_{4}+0.17 \mathrm{~mol} / \mathrm{L} \mathrm{NaCl}(\mathrm{pH} 3)$ solution [15].

We try to investigate the correlation between the carbide grain size and the pitting potential $E_{\mathrm{p}}$ for a given set of conditions. However, such a correlation is difficult to be discerned because $E_{\mathrm{p}}$ is affected by a combination of the testing parameters (e.g., exposure time, temperature, and scan range), the carbide grain size, and the texture of the material. Small variations in these parameters can result in large changes in $E_{\mathrm{p}}$, especially variations in the potentials of the experimental samples or in the solution temperature. In fact, efforts have been made to elucidate a relationship between the grain size and the pitting potential, but a specific relationship was difficult to be observed [20].

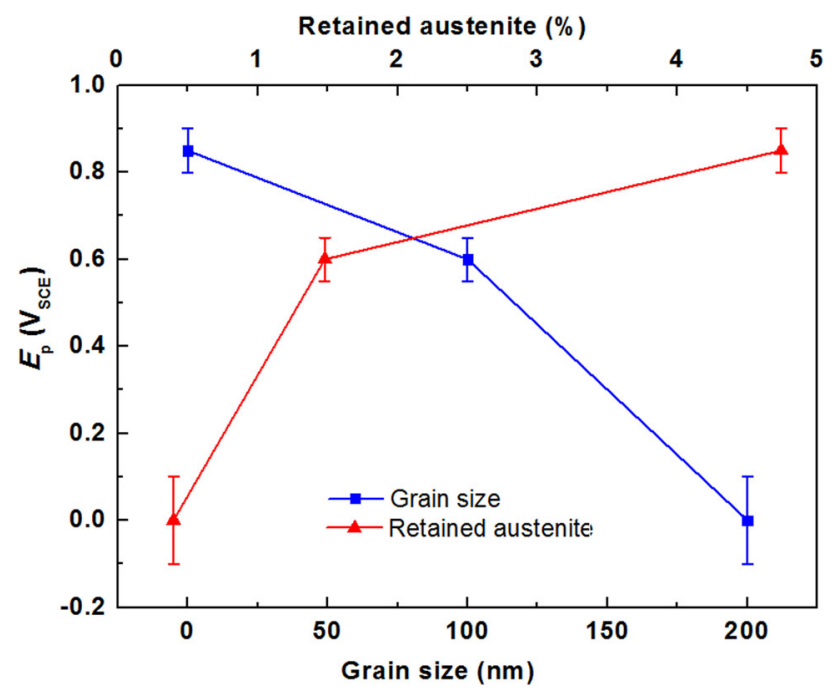

Fig. 7 Curves of pitting potential versus carbide grain size and amount of the retained austenite

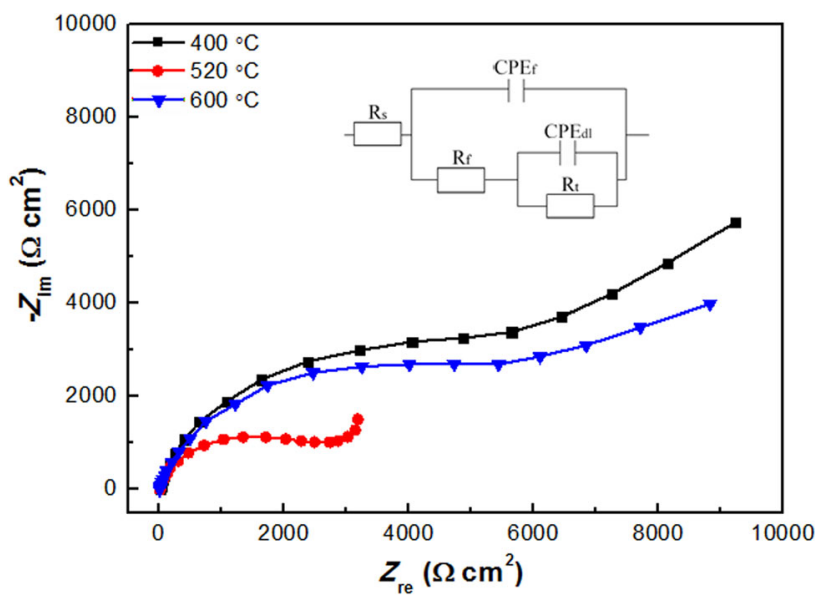

Fig. 8 EIS results of the UHSMSS in $0.1 \mathrm{~mol} / \mathrm{L} \mathrm{Na}_{2} \mathrm{SO}_{4}+0.17$ $\mathrm{mol} / \mathrm{L} \mathrm{NaCl}(\mathrm{pH} 3)$ solution

Figure 8 shows the EIS results for the steel specimens in $0.1 \mathrm{~mol} / \mathrm{L} \mathrm{Na} \mathrm{NO}_{4}+0.17 \mathrm{~mol} / \mathrm{L} \mathrm{NaCl}(\mathrm{pH}$ 3) solution. Similar impedance features are observable among the three samples; the electrochemical equivalent circuits are also shown in Fig. 8 (insert), where $R_{\mathrm{s}}$ is the solution resistance, $\mathrm{CPE}_{\mathrm{f}}$ is the double-charge-layer capacitance, $R_{\mathrm{f}}$ is the charge-transfer resistance, $\mathrm{CPE}_{\mathrm{dl}}$ is the capacitance of the corrosion product formed on the electrode surface, and $R_{\mathrm{t}}$ is the resistance of the corrosion product. The fitted parameters are given in Table 3. In the case of the steel tempered at $520{ }^{\circ} \mathrm{C}$, the carbide grain size is the largest, $R_{\mathrm{f}}$ is small, and $\mathrm{CPE}_{\mathrm{f}}$ is large; thus, this sample exhibits the worst corrosion resistance among the investigated samples. By contrast, in the case of the steel tempered at $400{ }^{\circ} \mathrm{C}, R_{\mathrm{f}}$ is the largest and $\mathrm{CPE}_{\mathrm{f}}$ is the smallest; thus, this sample exhibits the best corrosion resistance among the investigated samples.

\subsection{Effect of Retained Austenite on Corrosion Behavior}

Figure 7 also shows the amount of the retained austenite plotted against the pitting potential $E_{\mathrm{p}}$ for the steels heat treated under different conditions. $E_{\mathrm{p}}$ increases with increasing amount of the retained austenite. The shift of $E_{\mathrm{p}}$ in the more noble direction with increasing retained austenite content indicates the enhanced pitting resistance $[22,29]$. We assume that the retained austenite promotes the corrosion resistance of the steel in $0.1 \mathrm{~mol} / \mathrm{L} \mathrm{Na} \mathrm{Na}_{2}$ $\mathrm{SO}_{4}+0.17 \mathrm{~mol} / \mathrm{L} \mathrm{NaCl}(\mathrm{pH} 3)$ solution.

It is generally accepted that it affects strongly the electrochemical performances of the martensitic stainless steels. Retained austenite deteriorates the pitting corrosion resistance because of the formation of $\mathrm{Cr}$-depleted zones [30]. Although retained austenite has been demonstrated to deteriorate the tensile strengths and ductilities of the steels, 
Table 3 Values of fitting parameters observed from the Nyquist diagrams

\begin{tabular}{llllll}
\hline & $R_{\mathrm{s}}\left(\Omega \mathrm{cm}^{2}\right)$ & $\mathrm{CPE}_{\mathrm{f}}\left(\mu \mathrm{F} \mathrm{cm}{ }^{-2}\right)$ & $R_{\mathrm{f}}\left(\Omega \mathrm{cm}^{2}\right)$ & $\mathrm{CPE}_{\mathrm{dl}}\left(\mu \mathrm{F} \mathrm{cm}{ }^{-2}\right)$ & 0.002058 \\
\hline $400{ }^{\circ} \mathrm{C}$ & 12.72 & 0.0001562 & 7417 & 29295 \\
$520^{\circ} \mathrm{C}$ & 10.66 & 0.0001866 & 2987 & 0.008394 & 4158 \\
$600{ }^{\circ} \mathrm{C}$ & 8.487 & 0.0001476 & 6705 & 0.002451 & 5626 \\
\hline
\end{tabular}
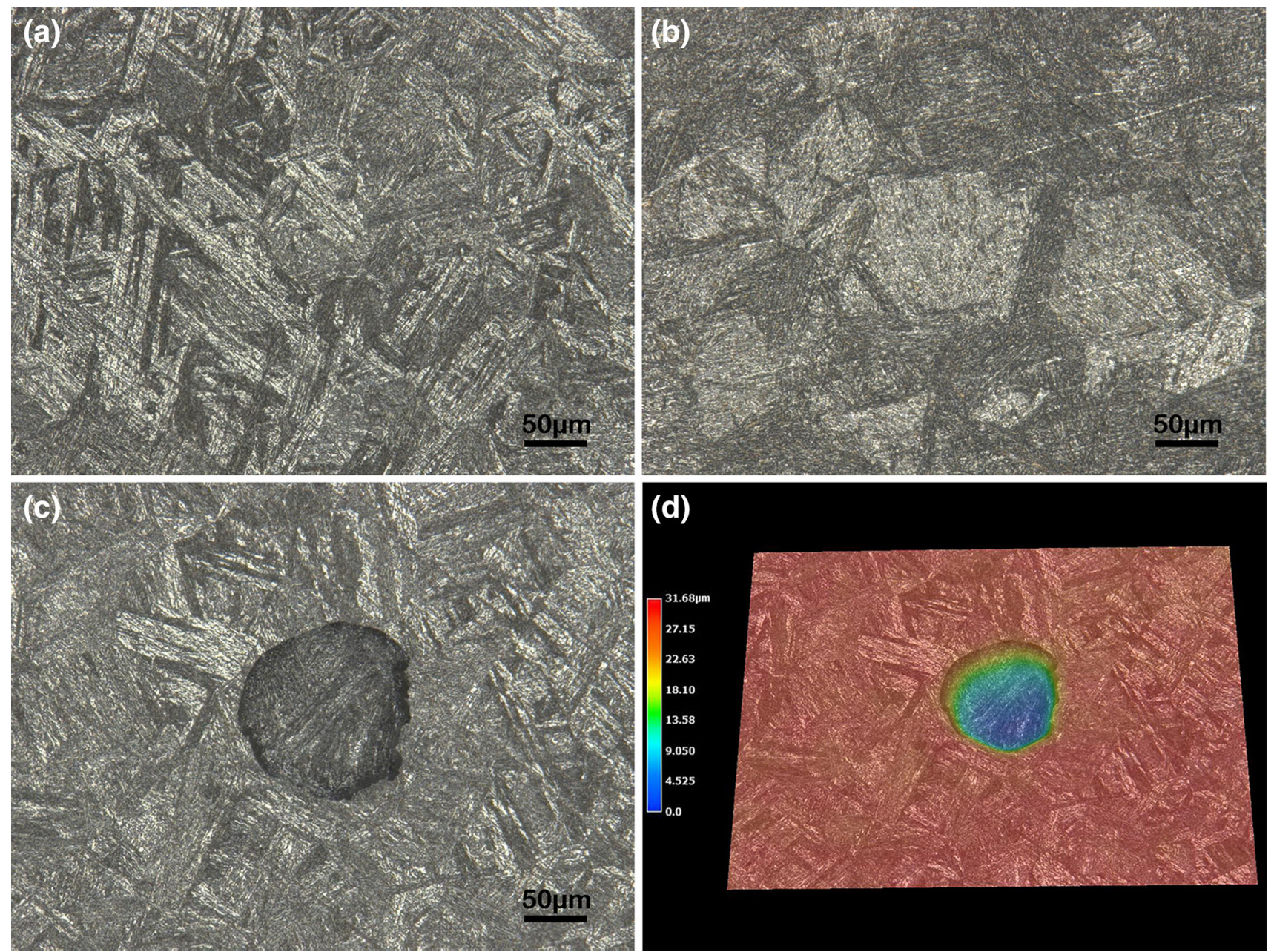

Fig. 9 Surface morphologies of the UHSMSS tempered at $400{ }^{\circ} \mathrm{C}(\mathbf{a}, \mathbf{c}, \mathbf{d})$ and $600{ }^{\circ} \mathrm{C}$ (b) after immersion for 10 min $(\mathbf{a}, \mathbf{b})$ and potentiodynamic polarization test $(\mathbf{c}, \mathbf{d})$ in $0.1 \mathrm{~mol} / \mathrm{L} \mathrm{Na}_{2} \mathrm{SO}_{4}+0.17 \mathrm{~mol} / \mathrm{L} \mathrm{NaCl}(\mathrm{pH}$ 1) solution

it nonetheless exists in our martensitic stainless steel. As previously illustrated, the steel tempered at $400{ }^{\circ} \mathrm{C}$ for $4 \mathrm{~h}$, which contains the largest amount of the retained austenite among the three investigated steel samples, exhibits the best resistance to pitting corrosion. Isolating the carbide grain size effect from the retained austenite effect is difficult. Therefore, we concluded that both the grain refinement and the increase in the amount of the retained austenite contribute to the improvement of the pitting corrosion resistance of UHSMSS. However, compared with the effect of the increase in the amount of retained austenite, the carbide grain refinement is the main contributor.

Figure 9 shows the surface morphologies of the UHSMSS tempered at 400 and $600{ }^{\circ} \mathrm{C}$ after immersion for $10 \mathrm{~min}$ and potentiodynamic polarization tests in $0.1 \mathrm{~mol} / \mathrm{L} \mathrm{Na}_{2}$ $\mathrm{SO}_{4}+0.17 \mathrm{~mol} / \mathrm{L} \mathrm{NaCl}(\mathrm{pH}$ 1) solution. As evident from Fig. 9a, b, when the UHSMSS was immersed in the strongly acidic solution, the surface state was clearly altered, initially by dissolution of the martensite and prior to austenite crystal boundaries. The UHSMSS exhibits pits with depths on the order of tens of microns in the solution with $\mathrm{pH} 1$. 


\section{Conclusions}

1. The microstructure of UHSMSS consists of retained austenite and lath/plant martensite with the carbides distributed within the matrix and at the boundaries.

2. The carbide grain size and the amount of the retained austenite are affected by the tempering temperature. The amount of the retained austenite in the microstructure of the UHSMSS decreases as the tempering temperature increases from 400 to $520{ }^{\circ} \mathrm{C}$ and increases as the tempering temperature increases from 520 to $600{ }^{\circ} \mathrm{C}$. The carbide grain size increases as the tempering temperature increases from 400 to $520^{\circ} \mathrm{C}$ and decreases as the tempering temperature increases from 520 to $600{ }^{\circ} \mathrm{C}$.

3. The carbides can induce pitting corrosion because larger carbide grains result in a lower pitting potential, thereby diminishing the steel's corrosion resistance. By contrast, the retained austenite improves the corrosion resistance of UHSMSS.

Acknowledgments This work was supported by the National Natural Science Foundation of China (No. 51171023), the Fundamental Research Funds for the Central Universities (No. FRF-TP-14-011C1), and National Basic Research Program of China (973 Program) (No. 2014CB643300).

\section{References}

[1] H. Krawiec, V. Vignal, O. Heintz, R. Oltra, E. Finot, J.M. Olive, Metall. Mater. Trans. A 35A, 3515 (2004)

[2] S. Marcelin, N. Pebere, S. Regnier, Electrochim. Acta 87, 32 (2013)

[3] A. Bojack, L. Zhao, P.F. Morris, J. Sietsma, Mater. Charact. 71, 77 (2012)

[4] C.X. Li, T. Bell, Corros. Sci. 48, 2036 (2006)

[5] S.K. Kim, J.S. Yoo, J.M. Priest, M.P. Fewell, Surf. Coat. Technol. 163-164, 380 (2003)

[6] M. Sun, K. Xiao, C.F. Dong, X.G. Li, P. Zhong, Corros. Sci. 89, $137(2014)$
[7] M. Sun, K. Xiao, C.F. Dong, X.G. Li, P. Zhong, Metall. Mater. Trans. A 44A, 4709 (2013)

[8] Z.Y. Zhang, Z.Y. Wang, Y.M. Jiang, H. Tan, D. Han, Y.J. Guo, J. Li, Corros. Sci. 62, 42 (2012)

[9] R.C. Fan, M. Gao, Y.C. Ma, X.D. Zha, X.C. Hao, K. Liu, J. Mater. Sci. Technol. 28, 1059 (2012)

[10] A. Pfennig, P. Zastrow, A. Kranzmann, Int. J. Greenh. Gas Control 15, 213 (2013)

[11] Y.Y. Song, X.Y. Li, L.J. Rong, D.H. Ping, F.X. Yin, Y.Y. Li, Mater. Sci. Eng., A 528, 4075 (2011)

[12] O.V. Akgun, M. Urgen, A.F. Cakir, Mater. Sci. Eng., A 203, 324 (1995)

[13] A.N. Isfahany, H. Saghafian, G. Borhani, J. Alloys. Compd. 509, 3931 (2011)

[14] S.M. Alvarez, A. Bautista, F. Velasco, Corros. Sci. 69, 130 (2013)

[15] J.Y. Park, Y.S. Park, Mater. Sci. Eng., A 449-451, 1131 (2007)

[16] C.A. Gervasi, C.M. Mendez, P.D. Bilmes, C.L. Llorente, Mater. Chem. Phys. 126, 178 (2011)

[17] K.M. Kim, J.H. Park, J.H. Kim, K.Y. Kim, Int. J. Hydrogen Energ. 36, 9926 (2011)

[18] C. Garcia, F. Martin, Y. Blanco, M.L. Aparicio, Corros. Sci. 52, 3725 (2010)

[19] C.L. Hu, S. Xia, H. Li, T.G. Liu, B.X. Zhou, W.J. Chen, N. Wang, Corros. Sci. 53, 1880 (2011)

[20] S.X. Li, Y.N. He, S.R. Yu, P.Y. Zhang, Corros. Sci. 66, 211 (2013)

[21] Y.S. Choi, J.G. Kim, Y.S. Park, J.Y. Park, Mater. Lett. 61, 244 (2007)

[22] P.D. Bilmes, C.L. Llorente, C.M. Méndez, C.A. Gervasi, Corros. Sci. 51, 876 (2009)

[23] Y.H. Yang, B. Yan, J. Li, J. Wang, Corros. Sci. 53, 3756 (2011)

[24] L.D. Chen, H. Tan, Z.Y. Wang, J. Li, Y.M. Jiang, Corros. Sci. 58, $168(2012)$

[25] Y.Z. Yang, Z.Y. Wang, H. Tan, J.F. Hong, Y.M. Jiang, L.Z. Jiang, J. Li, Corros. Sci. 65, 472 (2012)

[26] S. Kuimalee, T. CHairuangsri, J. Pearce, D. Edmonds, A. Brown, R. Brydson. Micron 41, 423 (2010)

[27] C.G. Andres, G. Caruana, L.F. Alvarez, Mater. Sci. Eng., A 241, 211 (1998)

[28] Y.B. Hu, C.F. Dong, M. Sun, K. Xiao, P. Zhong, X.G. Li, Corros. Sci. 53, 4159 (2011)

[29] P.D. Bilmes, C.L. Llorente, L. Huaman, L.M. Gassa, C.A. Gervasi, Corros. Sci. 48, 3261 (2006)

[30] S.T. Kim, S.H. Jang, I.S. Lee, Y.S. Park, Corros. Sci. 53, 1939 (2011) 